\title{
Impact of a gall midge Parkiamyia paraensis (Diptera, Cecidomyiidae) on the Amazonian plant Parkia pendula (Fabaceae)
}

\author{
G. Wilson Fernandes ${ }^{1,2}$, Jean Carlos Santos ${ }^{1}$,Fabiana Marize C. Castro ${ }^{1} \&$ Alexandre Castilho $^{3}$
}

${ }^{1}$ Ecologia Evolutiva \& Biodiversidade/DBG, ICB/Universidade Federal de Minas Gerais, Belo Horizonte-MG, Brazil. gwilson@icb.ufmg.br ${ }^{2}$ Planta Ltda, Belo Horizonte-MG, Brazil.

${ }^{3}$ Meio Ambiente, Mineração Rio do Norte, Porto Trombetas, Oriximiná-PA, Brazil.

\begin{abstract}
Impact of a gall midge Parkiamyia paraensis (Diptera, Cecidomyiidae) on the Amazonian plant Parkia pendula (Fabaceae). We observed the occurrence of large numbers of galls induced by Parkiamyia paraensis (Diptera, Cecidomyiidae) on the leaflets of Parkia pendula (Fabaceae) in northern Para, Brazil. We addressed two questions in this study: i) what is the proportion of attacked plants in the field, and nursery conditions?; and ii) what is the impact of galls on the host plant? An average of $86 \%$ of the plants were galled in the field. Galled P. pendula were distinct from healthy individuals due to their prostrated architecture and death of terminal shoots. Approximately 50\% of the total available leaves and $35 \%$ leaflets were attacked by P. paraensis on saplings under nursery conditions. Each one-year old plant supported an average of 1,300 galls, and an average of $60 \mathrm{~g}$ allocated to galled tissue. Otherwise, attacked individuals were taller and heavier than healthy plants. Attacked plants weighed five times more than healthy plants. When the weight of the galls was removed, the total weight (aerial part without galls) of attacked plants was drastically reduced, indicating that most of the biomass of attacked plants was due to the attack by P. paraensis galls. Although the data indicate a paradox, as young plants attacked by the galling herbivore appear to develop more vigorously than unattacked plants, we suggest that $P$. paraensis negatively affect $P$. pendula development.
\end{abstract}

KEYWORDS. Amazon; herbivore impact; insect galls; Porto Trombetas.

RESUMO. Impacto do galhador Parkiamyia paraensis (Diptera, Cecidomyiidae) sobre a planta da Amazônia Parkia pendula Benth. ex Walp. (Fabaceae). Observou-se a ocorrência de um grande número de galhas induzidas por Parkiamyia paraensis (Diptera, Cecidomyiidae) nos folíolos de Parkia pendula (Fabaceae) no norte do Pará, Brasil. Este estudo foi direcionado para responder duas perguntas: i) qual é a proporção de plantas atacadas no campo e em condições de estufa? e ii) qual é o impacto das galhas na planta hospedeira? Uma média de $86 \%$ das plantas apresentaram galhas no campo. Indivíduos com galhas de $P$. pendula eram distintos dos indivíduos saudáveis devido à arquitetura curvada e pela morte dos ramos terminais. Aproximadamente $50 \%$ do total de folhas e $35 \%$ dos folíolos de plantas jovens foram atacados por $P$. paraensis em condições de estufa. Para cada ano de idade, a planta apresentou uma média de 1.300 galhas e uma média de $60 \mathrm{~g}$ alocadas para o tecido galhado. Indivíduos atacados eram mais altos e mais pesados que plantas saudáveis. Plantas atacadas possuíam cinco vezes mais biomassa que plantas saudáveis. Quando o peso das galhas foi removido, o peso das plantas atacadas (parte aérea sem galhas) foi drasticamente reduzido, indicando que a maior parte da biomassa de plantas atacadas foi tomada pelas galhas de P. paraensis. Embora possa existir um paradoxo, onde plantas jovens atacadas por herbívoros galhadores desenvolvam mais vigorosamente do que plantas não atacadas, sugere-se que $P$. paraensis afetem negativamente o desenvolvimento de $P$. pendula.

PALAVRAS-CHAVE. Amazônia; galhas de insetos; impacto de herbívoros; Porto Trombetas.

The detrimental effects of gall-inducing insects on their host plant's growth and fitness have been documented numerous times (reviewed by Fernandes 1987). For instance, the impact of gallers on host quality and fitness has been used effectively in the biological control of some invasive plant species (e.g. Dennill 1985). An advantage of galling insects as biological control agents resides in their systemic impact on the host plant. Galls act as physiological nutrient sinks on their host plants, because nutrients move from healthy tissues and neighboring plant parts to the gall itself (e.g., McCrea et al. 1985). Galls also change the architecture of the attacked and neighboring host organs and sometimes the entire host plant (e.g., Mani 1964; Hartnett \& Abrahamson 1979; Fernandes et al. 1993; Goncalves-Alvim et al. 1999), often diminishing the development and performance of the host.

Many studies have shown a reduction in flower, fruit, seed, and biomass production caused by gall formation (e.g., McCrea et al. 1985; Sacchi et al. 1988; Fernandes \& Ribeiro 1990; Souza et al. 1998). Mirabilis linearis (Nyctaginaceae) attacked by a cecidomyiid gall inducer (Diptera, Cecidomyiidae) in the upper Sonoran Desert in northern Arizona had significantly fewer fruits than healthy plants and attacked stems showed significant reduction in fruit number compared to healthy adjacent stems (Fernandes et al. 1993). Potential viable fruit number was also decreased by gall formation, suggesting that galling insects had the potential to influence the success of their host plant by reducing fitness in susceptible individuals.

On the other hand, attack by some galling insects can increase plant growth and, hence, plant biomass. For instance, the attack by the galling species Euura lasiolepis (Hymenoptera, Tenthredinidae) on Salix lasiolepis (Salicaceae) induces the growth of new vegetative parts that are attacked in the next generation (Craig et al. 1990). Stems of Vernonia polyanthes (Asteraceae) attacked by the galling 
tephritid, Tomoplagia rudolphi (Diptera, Tephritidae) also produced more shoots and a larger number of inflorescences compared to healthy stems (Silva et al. 1996). Otherwise, the net effect may be detrimental to the host as attacked organs produce fewer viable seeds.

With the need to develop programs for the propagation of wild native species for land rehabilitation in the tropics, knowledge is being accumulated on the herbivores that feed on such species. In some cases galling insects are the most common herbivores of such plant species [e.g., Baccharis (Asteraceae) Fernandes et al. (1996), Bauhinia (Leguminosae) (Cornelissen \& Fernandes 2001)]. Species of the genus Chlorophora are severely impacted by galling psyllids of the genus Phytolyma (Homoptera: Psyllidae) in the forests of Ghana (Wagner et al. 1991). Perhaps another example in the tropical rain forest in the Amazon basin in Brazil is Parkia pendula (Willd.) Benth. ex Walp. (Fabaceae), popularly known as "fava-de-bolota" (Peres-Carlos 2000).

Parkia pendula is a common plant of the Amazonian rain forest (Lorenzi 2002). This species has been intensely propagated and used in a pioneer land rehabilitation program of the plateaus of Porto Trombetas, Para State, North Brazil. During a survey of insect galls on stands of planted native species and adjacent primary forest we observed the occurrence of large numbers of insect galls on the compound leaflets of $P$. pendula. Galls were so abundant that attacked plants could be spotted at a distance because of their distorted architecture. In an attempt to provide a first approximation of the impact this galling herbivore on this economically and ecologically valuable plant species, we address two questions: i) what is the frequency of attacked plants in the field?; and ii) what is the impact of galls on the host plant in the nursery.

\section{METHODS}

Parkia pendula (Willd.) Benth. ex Walp. (Fabaceae), popularly known as "fava-de-bolota", occurs in the "terra firme" forest of the Amazonian rain forest, and in the Atlantic rain forest of Bahia and Espírito Santo states in Brazil (Fig. $1 \mathrm{ab})$. It ranges from 20 to $30 \mathrm{~m}$ in height, and is an evergreen sun species. It flowers from August to October. Inflorescences and fruits hang from the branches giving it an ornamental appeal, encouraging its use as an ornamental species. Its wood can be used for civil construction, and furniture, among other uses (Lorenzi 2002). Furthermore, this species is widely used by fauna as their flowers, fruits, gum, and leaves are readily feed upon by birds, mammals (PeresCarlos 2000) and insects.

The galls are induced by a newly described species, Parkiamyia paraensis Maia (Diptera, Cecidomyiidae). They are green and formed by the union of two compound leaflets that assume the aspect of a pea (Maia \&Fernandes 2006) (Fig. $1 \mathrm{~d})$. When the attack is intense, galls may become coaslecent, stacking upon each other. Inside the one-chambered and glabrous galls only one larva is found. When mature, galls dehisce due to the opening of the gall equatorial plan.
Afterward, they become yellowish and then brown, and later fall off the plant. Generally, the galling insect emerges from the gall before dehiscence and leaves its exuvia attached to the gall wall at its equatorial plane (Maia \& Fernandes 2006).

Field observations were carried out in plantations of Amazonian native species in the Plateau Papagaio (01 ${ }^{\circ} 36$ ' 58.2 $\mathrm{S}$ and $56^{\circ} 24^{\prime} 14.4 \mathrm{~W}$ ), while laboratory observations were made at the nursery of the Mineração Rio do Norte S.A., Porto Trombetas, Pará State, Brazil both in November 2003 and April 2004. The native forest plantation was 14 months old (initiated in September 2002) when we conducted the preliminary field observations. Plants were grown from seeds collected in the primary forest early in August 2002. Seeds were germinated under ambient temperature, light, and humidity in open-air green houses and then transplanted to polypropylene bags $(1 \mathrm{Kg})$. After hardening they were planted in the field with a supplement of substrate composed of three parts of soil, two parts of manure, $10 \mathrm{~g}$ of micronutrients FTE BR-12 (powder= Zn $9.0 \%$, Mn 2.0\%, B 1.8\%, Mo 0.1\%, Cu 0.8\%, Fe 3.0\%, Co $0.0 \%), 130 \mathrm{~g}$ of NPK 04-14-08, and 40g of Yoorim ${ }^{\odot}$ fertilizer (granulate $=\mathrm{P}_{2} \mathrm{O}_{5}$ total $18.0 \%, \mathrm{P}_{2} \mathrm{O}_{5}$ solution of citric acid (at $2.0 \%) 13.0 \%$, Ca 20\%, Mg 7.0\%). Before planting, soil was corrected for acidity with $130 \mathrm{~g}$ of $\mathrm{CaO} 38 \%, \mathrm{MgO} 12.5 \%$, sum of oxides $50.5 \%$, PN $99.02 \%$, PRNT $90.01 \%$. Plants received no further fertilization or irrigation. All P. pendula individuals grew under the same environmental conditions (light, water, and nutrients).

To answer the question of galling attack rates in the field, additional observations on the density of attacked plants were carried out in April 2004. Two plots of 50x50 m were randomly marked in the Plateu Papagaio I $\left(01^{\circ} 38^{\prime} 22.5 \mathrm{~S}\right.$ and $56^{\circ} 26^{\prime}$ $27.9 \mathrm{~W})$, II ( $01^{\circ} 38^{\prime} 34.3 \mathrm{~S}$ and $\left.56^{\circ} 26^{\prime} 39.2 \mathrm{~W}\right)$, and III ( $01^{\circ} 37^{\prime}$ $57.7 \mathrm{~S}$ and $56^{\circ} 26^{\prime} 42.1 \mathrm{~W}$ ). All the plants sampled in the field did not possess more than three meters of height. We then counted all individuals of $P$. pendula found in each plot and recorded whether they had been attacked or not. In a single plot of each stand we recorded the percentage of plants that had their terminal parts dead as a result of galling. We also collected attacked leaves for evaluation of gall abundance and weight.

To answer the question on the impact of $P$. paraensis galls on the host plant, fifteen attacked and fifteen healthy one year-old plants were randomly selected in the nursery (Fig. $1 \mathrm{c})$. We assumed that the ambient exposed nursery plants were naturally colonized by the galling insects, that could be found only $15-25 \mathrm{~m}$ from adjacent primary forest. We recorded nursery plant's height, root and plant weight, number of compound leaves, number of healthy leaflets, total number of leaflets, number of attacked leaves, number of attacked leaflets, number of galls/leaflet, and, finally, the total number of galls. In an attempt to discount the weight of the galled tissue (galls) from healthy tissue on attacked plants, we estimated the expected weight that an attacked plant would have without galls by the formula: $E W=R * L$. $(E W=$ expected weight. $R=$ ratio between the length and weight of healthy plants. $L=$ Length of attacked plants). (* $=$ Multiplication). Finally, we 

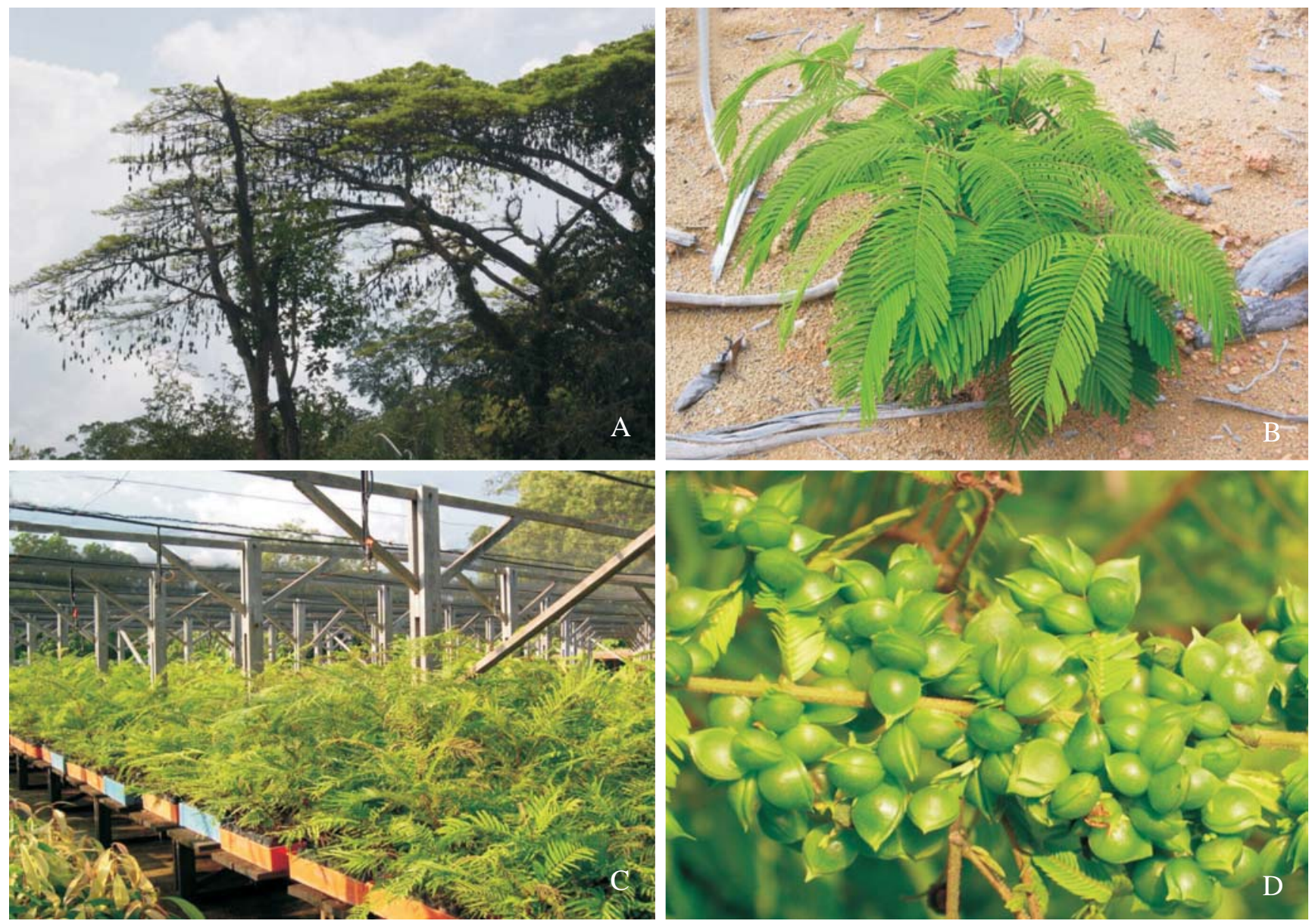

Fig. 1. A, Canopy of Parkia pendula (in evidence) in a primary Amazonian rain forest. B, Healthy P. pendula individual in forested stand. C, The nursery individuals under laboratorial conditions in Porto Trombetas, Pará State, Brazil. D, Parkiamyia paraensis leaf galls on P. pendula.

subtracted the expected weight from the weight of the galled plant (galls and healthy tissue). The data were analyzed by two-sample t-test (Zar 1996).

\section{RESULTS ANDDISCUSSION}

Field plants of $P$. pendula attacked by $P$. paraensis were easily found due to their prostrated architecture. Galling was so massive on some individuals that the attacked leaves and branches curved down. Due to the high abundance of galls, the terminal stems died back on many plant individuals. In April 2004, we observed that out of 86 attacked P. pendula plants in the three plots, approximately $72 \%$ of the plants attacked in previous year had their terminal parts killed by galling.

Casual observation indicated that the gall is spreading into the reforested areas. In November 2003 only a few $(<3 \%)$ individuals of $P$. pendula were attacked in the stand Plateau Papagaio 2002 I. In April 2004 galls had already spread to the neighboring stands, Papagaio 2002 II and III. Perhaps a factor that has been influential on this phenomenon is the fact that in the restored stands of Mineração Rio do Norte, plant species are placed at random in the field but much closer to each other and at considerably higher density than in the native forest. In the native forest of Porto Trombetas, individuals of a same species are often found hundreds of meters from its conspecific (see Parrotta et al. 1997). Furthermore, windy conditions, that could influence the dispersal potential of the galling insect, are certainly much more prevalent in the open stands as compared to the forest interior.

An average of 29 individuals of $P$. pendula was found per studied plot, representing approximately $5.4 \%$ of all plants present in the $250 \mathrm{~m}^{2}$ plots. Of this percentage, an average of $86.12 \%$ of the plants was attacked by P. paraensis in the field, with a range of $75.86 \%$ to $92.86 \%$.

Under nursery conditions, $P$. paraensis galls were very common on $P$. pendula. The average number of attacked leaves per plant was $7.3 \pm 1.9($ mean $\pm \mathrm{SD}, \mathrm{n}=15)$, which represented approximately $50 \%$ of the total available leaves on attacked saplings $(14.7 \pm 3.4$, mean $\pm \mathrm{SD}, \mathrm{n}=15)$. The average number of attacked leaflets per plant was $139.9 \pm 55.8($ mean $\pm S D, n=$ 15); hence representing approximately $35.24 \%$ (396.9 \pm 102.8 , mean $\pm \mathrm{SD}, \mathrm{n}=15$ ) of the available compound leaflets. The total average number of galls per one year-old plant was 1,271.8 


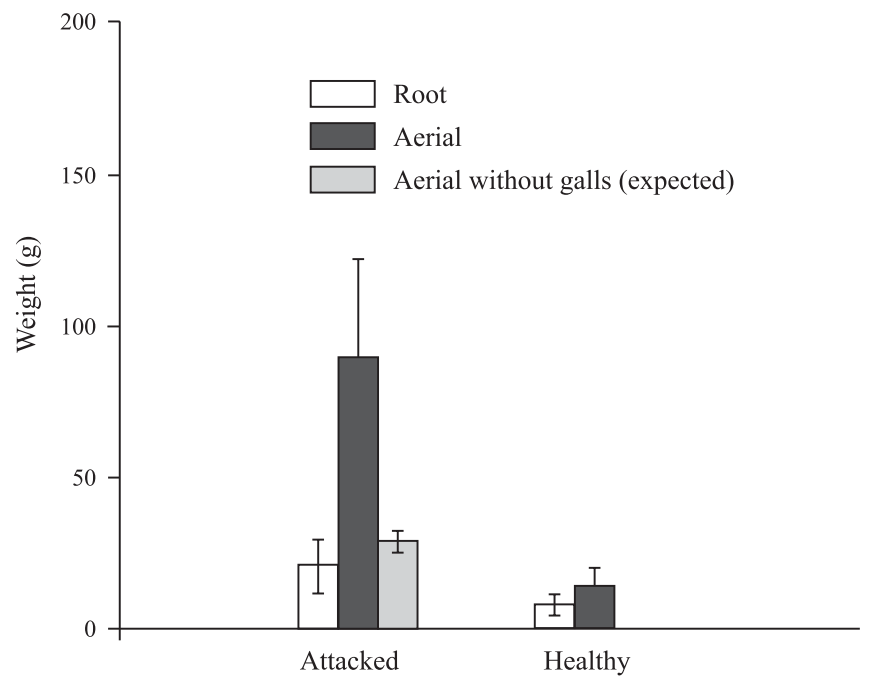

Fig. 2. Comparison of root and aerial weight of attacked and healthy individuals of Parkia pendula (Mimosaceae). Figure also shows the expected weight (weight of galls removed) of healthy tissue in attacked.

\pm 843.5 (mean $\pm \mathrm{SD}, \mathrm{n}=15$ ) while the average number of galls per leaflet was $8.5 \pm 3.6($ mean $\pm S D, n=15)$. Therefore, the average biomass allocated for the gall production per plant was $60.49 \pm 31.03 \mathrm{~g}($ mean $\pm \mathrm{SD}, \mathrm{n}=15)$ on one year-old nursery plants.

Under nursery condition, attacked plants were two-fold taller than healthy plants. The height of attacked individuals was $69.4 \pm 8.2 \mathrm{~cm}$ (mean $\pm \mathrm{SD}$ ) while the height of healthy plants was $32.8 \pm 10.1 \mathrm{~cm}$ (mean $\pm \mathrm{SD}$ ) (t-test $=10.91, p<0.0001$, $\mathrm{n}=30$ ). The biomass of attacked plants was also higher compared to healthy plants. The total weight (roots and aerial part with galls) of attacked plants was $110.2 \pm 37.2 \mathrm{~g}$ (mean \pm SD) whilst healthy plants weighed only $21.6 \pm 8.4 \mathrm{~g}$ (t-test $=$ $8.998, p<0.0001, \mathrm{n}=30$ ). Therefore, attacked plants by $P$. paraensis weighed five times more than healthy plants. Otherwise, when the weight of the galls was removed the total weight (roots and aerial part without galls) of attacked plants was reduced to $49.73 \pm 9.25 \mathrm{~g}$ (mean $\pm \mathrm{SD})(\mathrm{t}$-test $=8.706$, $p<0.0001, \mathrm{n}=30$ ). These data clearly show that most of the biomass of attacked seedlings was formed by galled tissue induced by $P$. paraensis.

When we separated the aerial parts from the roots to observe possible differential impact between parts of the same plant individual, the same trends were found. The aerial parts of attacked plants were six fold heavier compared to healthy plants (t-test $=9.07, p<0.0001, \mathrm{n}=30$, Fig. 2). When the weight of galls was removed from the aerial parts (expected weight), attacked plants continued to weigh more than the healthy plants (t-test $=8.294, p<0.0001, \mathrm{n}=30$, Fig. 2). The roots of attacked plants weighed almost three times more than the roots of healthy plants (t-test $=5.34, p<0.0001, \mathrm{n}=30$, Fig. 2).

Several studies have shown that galling attack promotes a reduction on the development and performance of its host plant (reviewed by Fernandes 1987; Harris 2002). One-year- old nursery $P$. pendula plants attacked by $P$. paraensis were, otherwise, larger and weighed more than healthy plants. These data may indicate a paradox as young plants attacked by the galling herbivore appears to develop more vigorously than unattached plants. On the other hand, females of P. paraensis may have selected the most vigorous hosts to lay their eggs (see Price 1991). Otherwise, the continued attack by galling insects and development in the field may result in diminished competitive ability with other plants and lower quality fruit and seed set. Much work is still needed to better understand the association of $P$. paraensis and its host plant both under experimental conditions (nursery and planted forest) and in the primary forest. Because $P$. pendula is a keystone plant resource in the Amazonian basin (Peres-Carlos 2000) and an increasingly important species used in restoration programs (Parrotta \& Knowles 2001), future work is needed to determine whether galling is a risk to be considered in restoration programs.

Acknowledgments. We thank PW Price and two anonymous reviewers for suggestions in the manuscript and Angelo Paiva for field help. This study was supported by the Mineração Rio do Norte, Planta Tecnologia Ambiental, and CNPq (47 9684/2001-4, 47 2491/2003-2, 30 4851/2004-3). A scholarship was provided to J.C. Santos by CNPq (140071/2003-2).

\section{REFERENCES}

Cornelissen, T. G. \& G. W. Fernandes. 2001. Patterns of attack of two herbivore guilds in the tropical shrub Bauhinia brevipes (Leguminosae): vigor or chance? European Journal of Entomology 98: 37-40.

Craig, T. P.; J. K. Itami \& P. W. Price. 1990: Intraspecific competition and facilitation by a shoot-galling sawfly. Journal Animal Ecology 59: 147-159

Dennill, G. B. 1985. The effect of the gall wasp Trichilogaster acaciaelongifoliae (Hymenoptera: Pteromalidae) on reproductive potential and vegetative growth of the weed Acacia longifolia. Agriculture, Ecosystems and Environment 14: 53-61.

Fernandes, G. W. \& S. P. Ribeiro. 1990. Plant response to herbivory: two examples from the neotropics. Ecotropicos 3: 77-86.

Fernandes, G. W. 1987. Gall forming insects: their economic importance and control. Revista Brasileira de Entomologia 31: 379-398.

Fernandes, G. W.; M. A. A. Carneiro; A. C. F. Lara; L. A. Allain; G. I. Andrade; G. Julião; T. C. Reis \& I. M. Silva. 1996. Galling insects on neotropical species of Baccharis (Asteraceae). Tropical Zoology 9: 315-332.

Fernandes, G. W.; A. L. Souza \& C. F. Sacchi. 1993. Impact of a Neolasioptera (Cecidomyiidae) stem gall on its host plant Mirabilis linearis (Nyctaginaceae). Phytophaga 5: 1-6.

Gonçalves-Alvim, S. J.; E. C. Landau; M. Fagundes; V. G. Silvia; R. F. Nunes \& G. W. Fernandes. 1999. Abundance and impact of a lepidopteran gall on Machaeiera sp. (Melastomataceae) in the neotropics. International Journal of Ecology and Environmental Sciences 25: 115-125.

Harris, K. M. 2002. A review of the Cecidomyiidae (gall midge) that are important pest of world food crops. Atti dell'Accademia Nazionale Italiana di Entomologia 1: 97-106.

Hartnett, D. C. \& W. G. Abrahamson. 1979. The effects of stem gall insects on life history in Solidago canadensis. Ecology 60: 910917.

Lorenzi, H. 2002. Árvores brasileiras. Manual de identificação e cultivo de plantas arbóreas nativas do Brasil. Instituto 
Plantarum, Nova Odessa, $4^{\text {th }}$ ed., 384 p.

Mani, M. S. 1964. The ecology of plant galls. Junk, The Hague, The Netherlands, $464 \mathrm{p}$.

Maia, V. C. \& G. W. Fernandes. 2006. A new genus and species of gall midge (Diptera, Cecidomyiidae) associated with Parkia pendula (Fabaceae, Mimosoideae). Revista Brasileira de Entomologia 50: $1-5$.

Mccrea, K. D.; W. G. Abrahamson \& A. E. Weis. 1985. Goldenrod ball gall effects on Solidago altissima: ${ }^{14} \mathrm{C}$ translocation and growth. Ecology 66: 1902-1907.

Parrotta, J. A. \& O. H. Knowles. 2001. Restoring tropical forests on lands mined for bauxite. Ecological Engineering 17: 219-239.

Parrotta, J. A.; O. H. Knowles \& J. M. Wunderle. 1997. Development of floristic diversity in 10-year-old restoration forests on a bauxite mined site in Amazonia. Forest Ecology and Management 99: 21-42.

Peres-Carlos, A. 2000. Identifying keystone plant resources in tropical forests: the case of gums from Parkia pods. Journal of Tropical Ecology 16: 287-317.
Price, P. W. 1991. The plant vigor hypothesis and herbivore attack. Oikos 62: 244-251.

Sacchi, C. F.; P. W. Price; T. P. Craig \& J. K. Itami. 1988. Impact of the shoot galler attack on sexual reproduction in the arroyo willow. Ecology 69: 2021-2030.

Silva, I. M.; G. I. Andrade; G. W. Fernandes \& J. P. Lemos Filho. 1996. Parasitic relationships between a gall forming insect Tomoplagia rudolphi (Diptera: Tephritidae) and its host plant (Vernonia polyanthes, Asteraceae). Annals of Botany 78: 45-48.

Souza, A. L. T.; G. W. Fernandes; J. E. C. Figueira \& M. O. Tanaka. 1998. Natural history of a gall-inducing weevil Collabismus clitellae (Coleoptera: Curculionidae) and some effects on its host plant Solanum lycocarpum (Solanaceae) in southeastern Brazil. Annals of the Entomologycal Society of America 91: 404-409.

Wagner, M. R.; S. K. N. Atuahene \& J. R. Cobbinah, 1991. Forest entomology in west tropical Africa: Forest insects of Ghana. Kluwer Academic, Dorderech, $210 \mathrm{p}$.

Zar, J. H. 1996. Biostatistical Analysis. Prentice-Hall, Englewood Cliffs, New Jersey. $4^{\text {th }}$ ed., 929 p.

Received 21/09/2006; accepted 04/09/2007 